\title{
Evaluation Studies to Indicate Wide Diversity in Qualitative Traits of Sesame Germplasm in Madhya Pradesh Region
}

\author{
Nitesh Kumar Panwar* and Rajani Bisen \\ Department of Plant Breeding and Genetics, Jawaharlal Nehru Krishi Vishwa Vidyalaya, \\ Jabalpur (M.P.) 482004, India \\ *Corresponding author
}

\begin{tabular}{l} 
K e y w o r d s \\
$\begin{array}{l}\text { Candidate } \\
\text { genotypes, Gene- } \\
\text { pool, } \\
\text { Morphological } \\
\text { variations and } \\
\text { Genetic makeup etc }\end{array}$ \\
Article Info \\
$\begin{array}{l}\text { Accepted: } \\
\text { 18 August } 2020 \\
\text { Available Online: } \\
\text { 10 September } 2020\end{array}$ \\
\hline
\end{tabular}

\section{A B S T R A C T}

\section{Introduction}

Sesame (Sesamum indicum L., $2 \mathrm{n}=26$ ) is an important ancient oilseed crop adapted to tropical and subtropical areas (Frary et al., 2015). Africa has been considered to be the primary centre of origin of sesame and it spread through West Asia to India, China and
Japan, which themselves became secondary centre of origin (Weiss, 1983). The genus Sesamum consists of many species and the most cultivated species is Sesamum indicum L. (Ashri, 1998). Sesame described as the "Queen of oil seed crops" (Deepthi et al., 2014) because it contains high oil (38-54\%), protein $(18-25 \%)$, calcium, phosphorous, 
oxalic acid and excellent qualities of seed oil and meal (Prasad, 2002). Sesamum seed oil has long shelf life due to the presence of lignans viz., Sesamin, Sesaminol and Sesamolinol which have antioxidant properties, highly resistant to oxidative deterioration and significant amount of oleic and linoleic acids (Abate and Mekbib, 2015).

Cultivated sesame has high variability in their genotypes. Germplasm forms the raw material for any crop improvement programme (Upadhayay et al., 2010). Qualitative characters are generally highly heritable, can be easily seen by the eye and are equally expressed in all environments. Qualitative characters are considered as morphological markers in the identification of landraces, because they are less influenced by environmental changes and the most common approach utilized to estimate relationships between genotypes (Gour et al., 2018). Germplasm characterization and evaluation studies indicate wide diversity in Qualitative characters. Since several morphological characters (descriptors) remain the only legitimate marker types desirable by a consensus of users of the particular crop and accepted by the NBPGR and International Union for the Protection of New Varieties of Plants (NBPGR guideline, 2004). For identification of varieties through morphological characters and conduct of GOT, the plant and seed characters need to be studied and thoroughly documented (Bhoot et al., 2019). Therefore, we are trying to determine the best course of action at this point of qualitative characterization.

\section{Materials and Methods}

The experimental material comprised of 829 sesame germplasm obtained from Project Coordinating Unit, All India Coordinated Research Project on Sesame and Niger (Indian Council of Agricultural Research),
JNKVV Campus, Jabalpur, Madhya Pradesh, India and grown using unreplicated Augmented Block Design (Federer, 1956) during Kharif 2019. The distance between rows was maintained at $30 \mathrm{~cm}$ and plant to plant $10 \mathrm{~cm}$. The recommended agronomical and plant protection package of practices were followed for raising successful crop.

Data were collected on 17 morphological characters. The observations of various characteristics were recorded at different stages of growth with appropriate procedures as per the NBPGR and DUS test guidelines of PPV \& FR Authority, GOI, New Delhi (Table 1). The observations were recorded i.e., plant growth habit, stem hairiness, branching pattern, leaf hairiness, leaf shape, leaf size, basal leaf margin, lobe incision of basal leaf, number of flowers per leaf axil, corolla hairiness, corolla colour, number of locules per capsule, bicarpellate capsule shape, capsule arrangement, capsule hairiness, colour of dry Capsule and capsule beak.

\section{Results and Discussion}

Overall 829 germplasm were used for morphological characterization (Table 1). Seventeen morphological traits on five randomly chosen plants of each line were observed and characterized according to the National Test Guidelines by NBPGR and DUS guidelines (Fig. 1-3).

In case of plant growth habit (Fig.6) maximum number of germplasm was semierect (760) followed by erect (46) and prostrate (23). Erect, semi-erect and prostrate growth habit is another important agronomic trait, because a dense ground cover affects the interception of light for photosynthetic accumulation, the inhibition of weed growth and the reduction of water evaporation from soil (Baum et al., 2003). Non-branching, basal and top branching (Fig.7) pattern were 
exhibited 21, 463 and 345 germplasm, respectively.

Hairiness and pubescence is natural and wild type characteristics in various plant species (Tian et al., 2012). In our study, 27 germplasm exhibited absent, 217 germplasm sparse and 590 germplasm were found dense in corolla hairiness (Fig.4). Corolla hairiness is well preventing measure for the loss of water in flower at high temperatures, it is often preferred because it is considered to have a positive impact on the pollination of flowers (Ozcinar and Sogut, 2017). Similarly, 466 germplasm exhibited sparse and 89 germplasm exhibited medium leaf hairiness and was absent in 274 germplasm.

Leaf hairiness helps in protective leaves from excessive sunlight and may be related to resistance to wilting and drought tolerance in sesame and other species (Bedigian, 2004). In case of stem hairiness (Fig.6), sparse hairiness was recorded in 449 germplasm, followed by glabrous in 319 germplasm and medium stem hairiness in 56 germplasm.

Capsule hairiness (Fig.8) was observed to be strong or profuse in 322 germplasm followed by weak or sparse in 302 germplasm, glabrous or absent in 111 germplasm and medium capsule hairiness in 94 germplasm. Hairiness and pubescence are reported to be natural defense mechanism for biotic and abiotic factors and that they are rich in defense related proteins also (Amme et al., 2005). So this character may be recognized as ideotype for sesame crop (Frary et al., 2015; Palakshappa et al., 2020).

The shape and the size of the leaves are controlled genetically. Regarding the leaf shape trait (Fig.5), the data recorded middle and top leaves separately i.e., leaf shape of middle leaves observed ovate in 725 germplasm followed by narrowly cordate in
73, elliptic in 23 and lanceolate in 8 germplasm whereas, top leaves observed linear for 560 germplasm followed by lanceolate in 269 germplasm. In case of leaf size (Fig.5), medium leaf size was observed in 507 germplasm followed by large in 170 germplasm and small leaf size in 152 germplasm.

The timing of the data collection is also important because the differences in rates of decrease in leaf sizes may end up with lower ratings on some lines just by taking the data ten days later. Lines planted side-by-side in multiple locations and environments will have the same relative sizes within one place even whereas, small leafed lines in one location can be larger in another location. While it is clear that moisture and fertility increase leaf size, the effects of population density, light, and degree days also has effect (Langham, 2007).

Majority of germplasm were having entire type of basal leaf margin (720) and only 91 and 18 germplasm were serrate and dentate type of basal leaf margin (Fig.5), respectively. With respect to lobe incision of basal leaf (Fig.6) most of germplasm (521) do not have lobes on basal leaf and 133 germplasm recorded strong lobe incision on basal leaf followed by weak in 105 and medium lobe incision on basal leaf in 70 germplasm. Similar finding were found by Jadhav et al., 2015.

Only thirty three germplasm have more than one flower per leaf axil and remaining all the germplasm have one flower per leaf axil (Fig.4). With regard to this trait it was determined that the number of flowers in the axil affects fertilization, the number of capsules and efficiency so that trait should be of great importance (Ozcinar and Sogut, 2017). 
Table.1 Frequency distribution and percent score of morphological traits in Sesame germplasm lines

\begin{tabular}{|c|c|c|c|c|c|}
\hline S. No. & Morphological traits & Observations & Score & Frequency observed & Percent score \\
\hline 1. & Plant growth habit & $\begin{array}{l}\text { Prostrate } \\
\text { Semi-erect } \\
\text { Erect }\end{array}$ & $\begin{array}{l}1 \\
2 \\
3\end{array}$ & $\begin{array}{l}23 \\
760 \\
46\end{array}$ & $\begin{array}{l}2.77 \\
91.67 \\
5.54\end{array}$ \\
\hline 2. & Stem hairiness & $\begin{array}{l}\text { Glabrous } \\
\text { Sparse } \\
\text { Medium }\end{array}$ & $\begin{array}{l}0 \\
3 \\
5\end{array}$ & $\begin{array}{l}319 \\
449 \\
61\end{array}$ & $\begin{array}{l}38.48 \\
54.16 \\
7.35\end{array}$ \\
\hline 3. & Branching pattern & $\begin{array}{l}\text { Non-branching } \\
\text { Basal branching } \\
\text { Top branching }\end{array}$ & $\begin{array}{l}0 \\
1 \\
2\end{array}$ & $\begin{array}{l}21 \\
463 \\
345\end{array}$ & $\begin{array}{l}2.53 \\
55.85 \\
41.61\end{array}$ \\
\hline 4. & Leaf hairiness & $\begin{array}{l}\text { Glabrous } \\
\text { Sparse } \\
\text { Medium } \\
\text { Strong }\end{array}$ & $\begin{array}{l}0 \\
3 \\
5 \\
7\end{array}$ & $\begin{array}{l}274 \\
466 \\
89 \\
0\end{array}$ & $\begin{array}{l}33.05 \\
56.21 \\
10.73 \\
0.00\end{array}$ \\
\hline \multirow[t]{4}{*}{5.} & \multirow[t]{4}{*}{ Leaf shape } & \multicolumn{4}{|l|}{ Middle leaves- } \\
\hline & & $\begin{array}{l}\text { Linear } \\
\text { Lanceolate } \\
\text { Elliptic } \\
\text { Ovate } \\
\text { Narrowly cordate }\end{array}$ & $\begin{array}{l}1 \\
2 \\
3 \\
4 \\
5\end{array}$ & $\begin{array}{l}0 \\
8 \\
23 \\
725 \\
73\end{array}$ & $\begin{array}{l}0.00 \\
0.96 \\
2.77 \\
87.45 \\
8.80\end{array}$ \\
\hline & & \multicolumn{4}{|l|}{ Top leaves- } \\
\hline & & $\begin{array}{l}\text { Linear } \\
\text { Lanceolate } \\
\text { Elliptic } \\
\text { Ovate }\end{array}$ & $\begin{array}{l}1 \\
2 \\
3 \\
4\end{array}$ & $\begin{array}{l}560 \\
269 \\
0 \\
0\end{array}$ & $\begin{array}{l}67.55 \\
32.44 \\
0.00 \\
0.00\end{array}$ \\
\hline 6. & Basal leaf margin & $\begin{array}{l}\text { Entire } \\
\text { Serrate } \\
\text { Dentate }\end{array}$ & $\begin{array}{l}1 \\
2 \\
3\end{array}$ & $\begin{array}{l}720 \\
91 \\
18\end{array}$ & $\begin{array}{l}86.85 \\
10.97 \\
2.17\end{array}$ \\
\hline 7. & Lobe incision of basal leaf & $\begin{array}{l}\text { Absent } \\
\text { Weak } \\
\text { Medium } \\
\text { Strong }\end{array}$ & $\begin{array}{l}0 \\
3 \\
5 \\
7\end{array}$ & $\begin{array}{l}521 \\
105 \\
70 \\
133\end{array}$ & $\begin{array}{l}62.84 \\
12.66 \\
8.44 \\
16.04\end{array}$ \\
\hline 8. & Number of flowers per leaf axil & $\begin{array}{l}\text { One } \\
\text { More than one }\end{array}$ & $\begin{array}{l}1 \\
2\end{array}$ & $\begin{array}{l}796 \\
33\end{array}$ & $\begin{array}{l}96.01 \\
3.98\end{array}$ \\
\hline 9. & Corolla colour & $\begin{array}{l}\text { White } \\
\text { White with pink shading } \\
\text { White with deep pink } \\
\text { shading }\end{array}$ & $\begin{array}{l}1 \\
2 \\
3\end{array}$ & $\begin{array}{l}31 \\
752 \\
46\end{array}$ & $\begin{array}{l}3.73 \\
90.71 \\
5.54\end{array}$ \\
\hline 10. & Corolla hairiness & $\begin{array}{l}\text { Absent } \\
\text { Sparse } \\
\text { Dense }\end{array}$ & $\begin{array}{l}1 \\
3 \\
5\end{array}$ & $\begin{array}{l}27 \\
212 \\
590\end{array}$ & $\begin{array}{l}3.25 \\
25.57 \\
71.17\end{array}$ \\
\hline 11. & Leaf size & $\begin{array}{l}\text { Small } \\
\text { Medium } \\
\text { Large }\end{array}$ & $\begin{array}{l}3 \\
5 \\
7\end{array}$ & $\begin{array}{l}152 \\
507 \\
170\end{array}$ & $\begin{array}{l}18.33 \\
61.15 \\
20.50\end{array}$ \\
\hline 12. & Capsule hairiness & $\begin{array}{l}\text { Glabrous } \\
\text { Sparse } \\
\text { Medium } \\
\text { Strong }\end{array}$ & $\begin{array}{l}0 \\
3 \\
5 \\
7\end{array}$ & $\begin{array}{l}111 \\
302 \\
94 \\
322\end{array}$ & $\begin{array}{l}13.38 \\
36.42 \\
11.33 \\
38.84\end{array}$ \\
\hline 13. & Number of locules per capsule & $\begin{array}{l}\text { Four } \\
\text { Six } \\
\text { Eight }\end{array}$ & $\begin{array}{l}1 \\
2 \\
3\end{array}$ & $\begin{array}{l}802 \\
12 \\
15\end{array}$ & $\begin{array}{l}96.74 \\
1.44 \\
1.80\end{array}$ \\
\hline 14. & Bicarpellate capsule shape & $\begin{array}{l}\text { Tapered at apex } \\
\text { Narrow oblong } \\
\text { Broad oblong }\end{array}$ & $\begin{array}{l}1 \\
2 \\
3\end{array}$ & $\begin{array}{l}5 \\
745 \\
79\end{array}$ & $\begin{array}{l}0.60 \\
89.86 \\
9.16\end{array}$ \\
\hline 15. & Capsule arrangement & $\begin{array}{l}\text { Monocapsular } \\
\text { Multicapsular }\end{array}$ & $\begin{array}{l}1 \\
2\end{array}$ & $\begin{array}{l}796 \\
33\end{array}$ & $\begin{array}{l}96.01 \\
3.98\end{array}$ \\
\hline 16. & Capsule beak & $\begin{array}{l}\text { Short } \\
\text { Long } \\
\text { Curved }\end{array}$ & $\begin{array}{l}1 \\
2 \\
3\end{array}$ & $\begin{array}{l}506 \\
229 \\
94\end{array}$ & $\begin{array}{l}61.03 \\
27.62 \\
11.33\end{array}$ \\
\hline 17. & Colour of dry capsule & $\begin{array}{l}\text { Straw/Yellow } \\
\text { Brown/Tan }\end{array}$ & $\begin{array}{l}2 \\
3\end{array}$ & $\begin{array}{l}814 \\
15\end{array}$ & $\begin{array}{l}98.19 \\
1.80\end{array}$ \\
\hline
\end{tabular}


Fig.1 Bar diagram showing frequency distribution of different morphological traits in Sesame
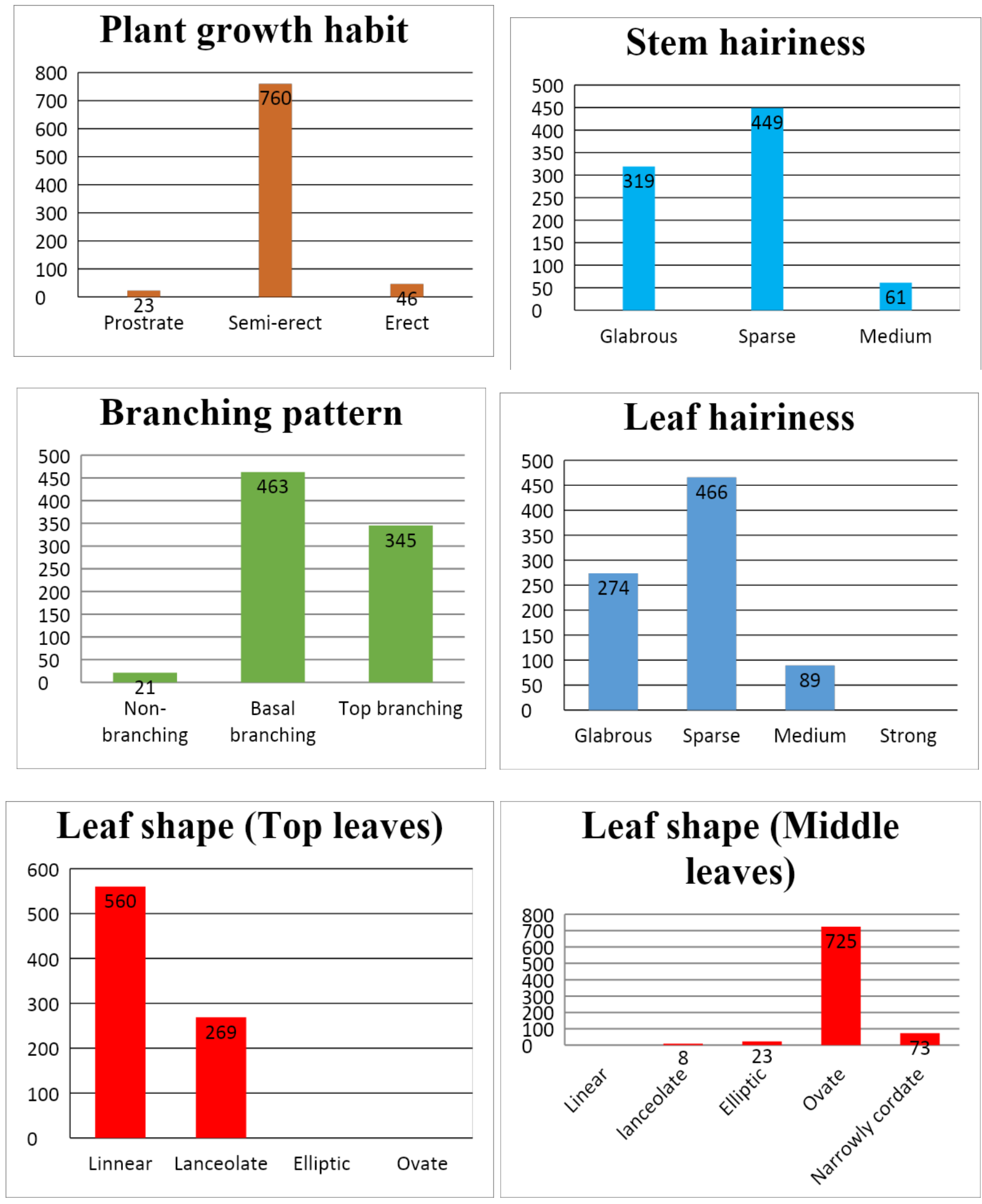
Fig.2 Bar diagram showing frequency distribution of different morphological traits in Sesame
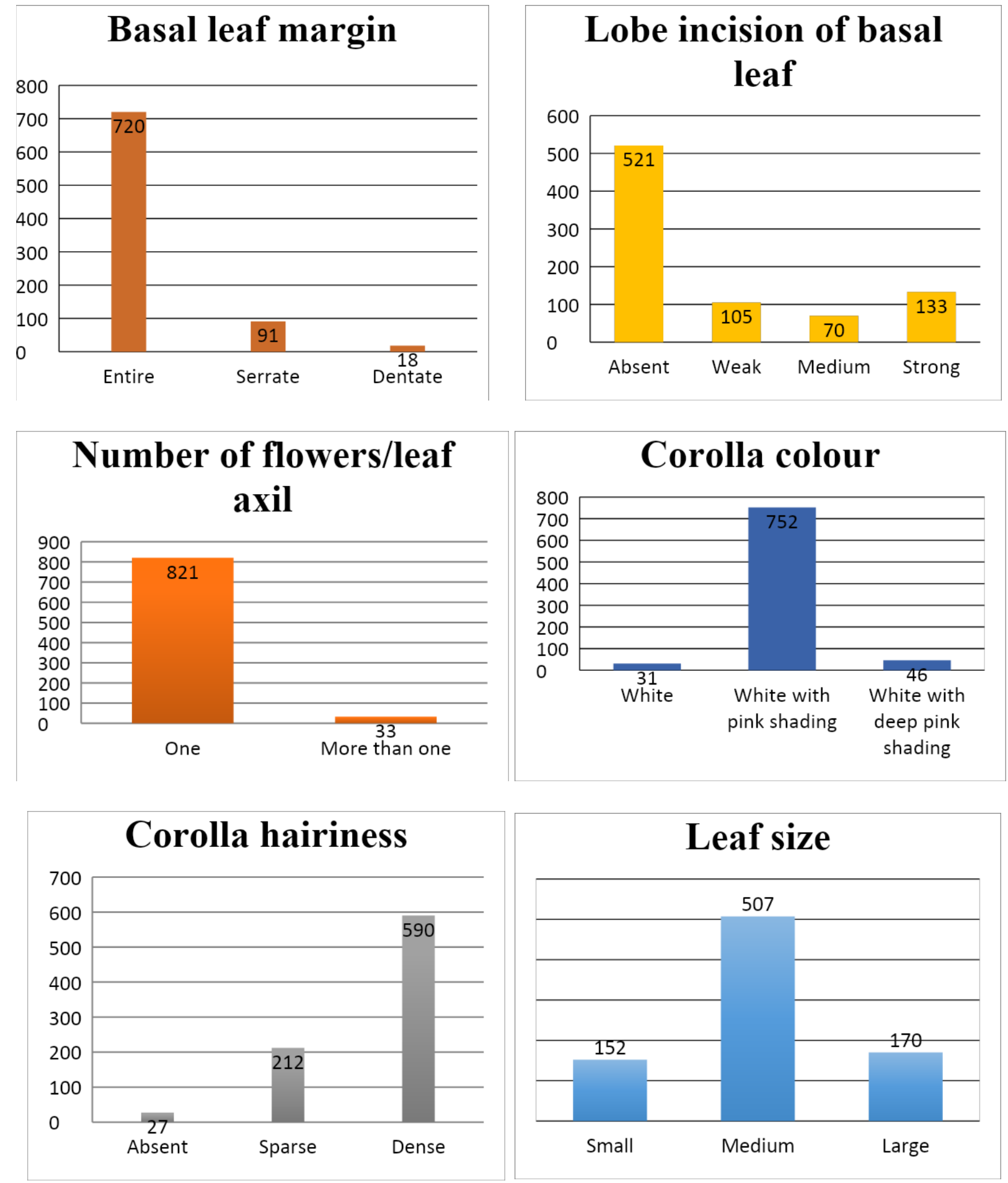
Fig.3 Bar diagram showing frequency distribution of different morphological traits in Sesame
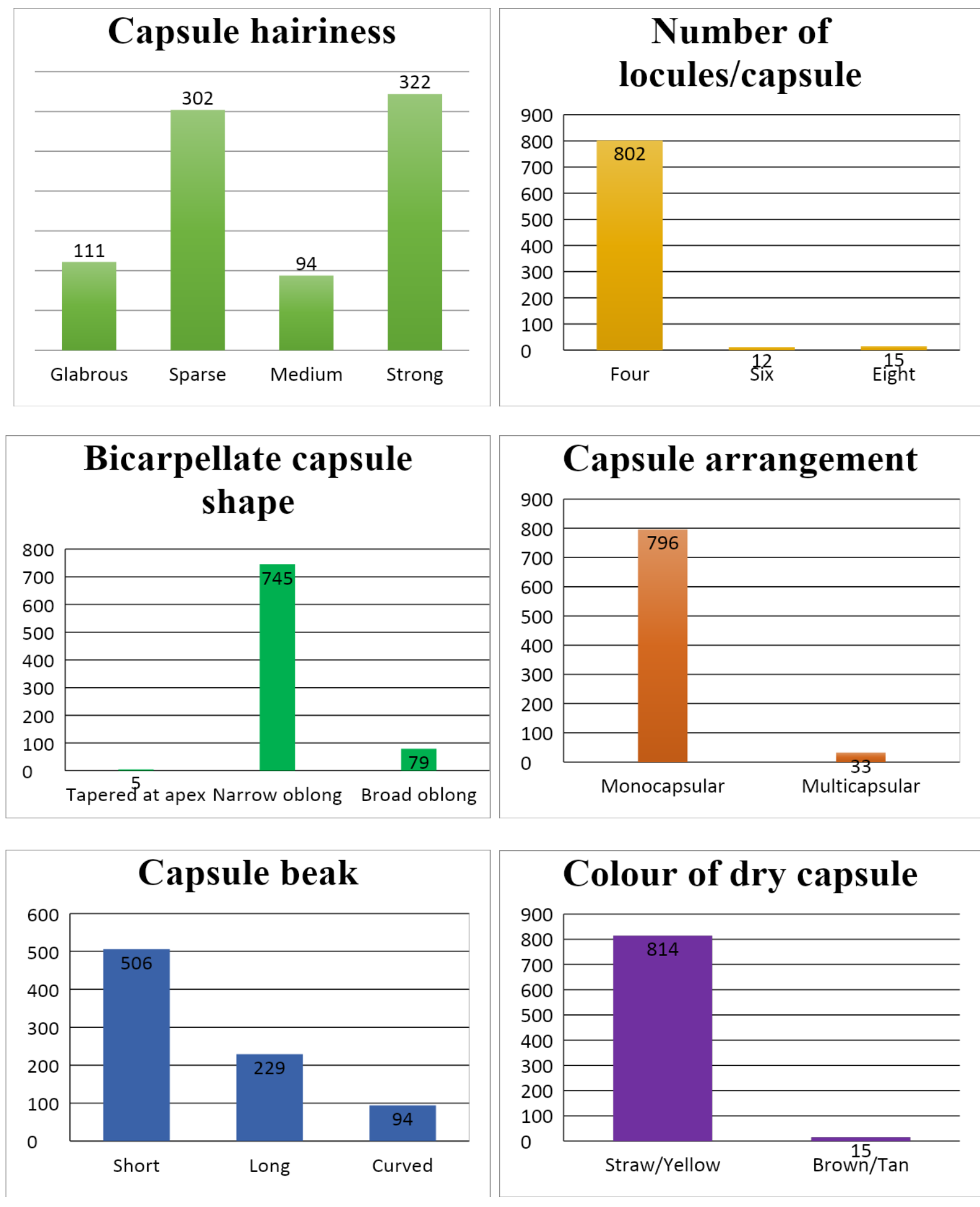
Fig.4 Diagram showing of different morphological traits in Sesame

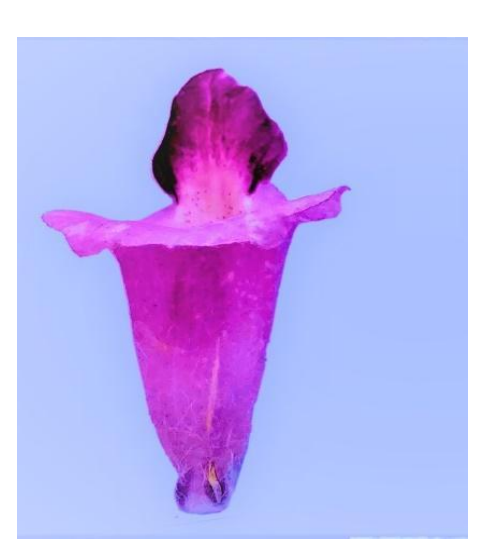

White with deep pink shading

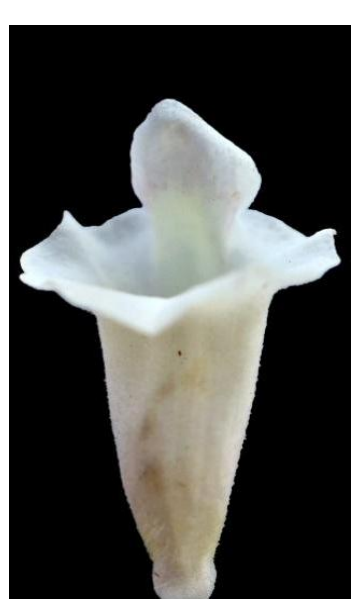

Absent

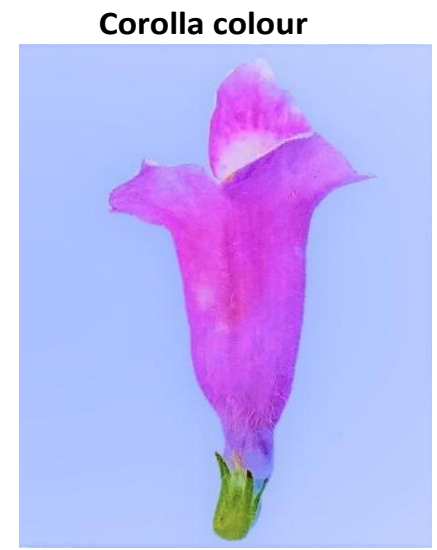

White with pink shading

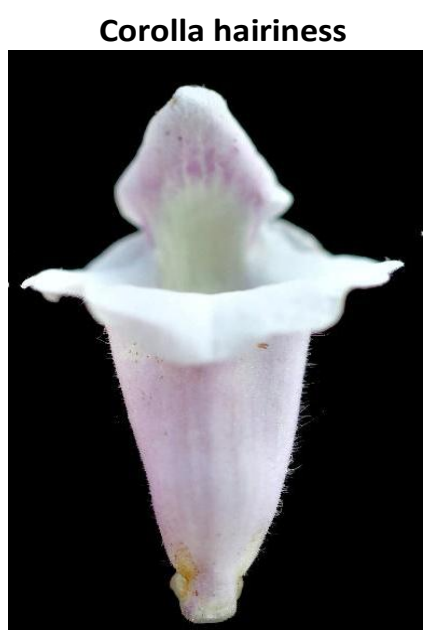

Sparse

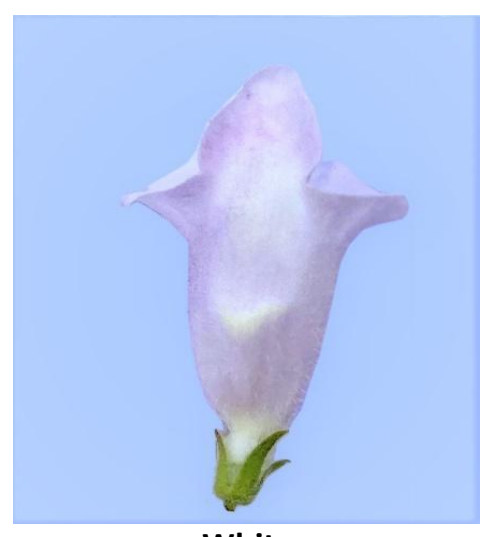

White

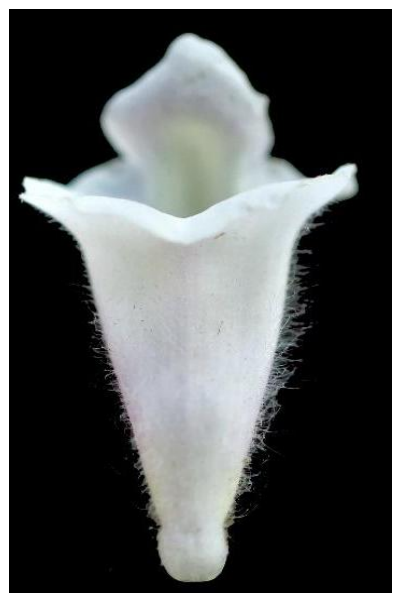

Dense

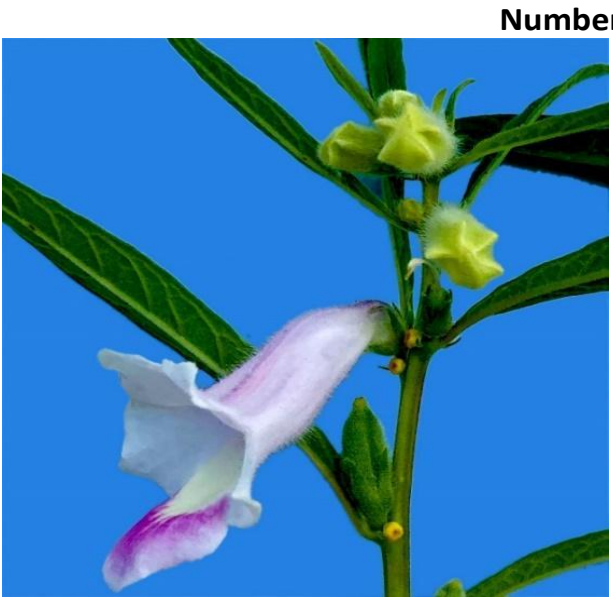

One flower/axil

Number of flower/leaf axil

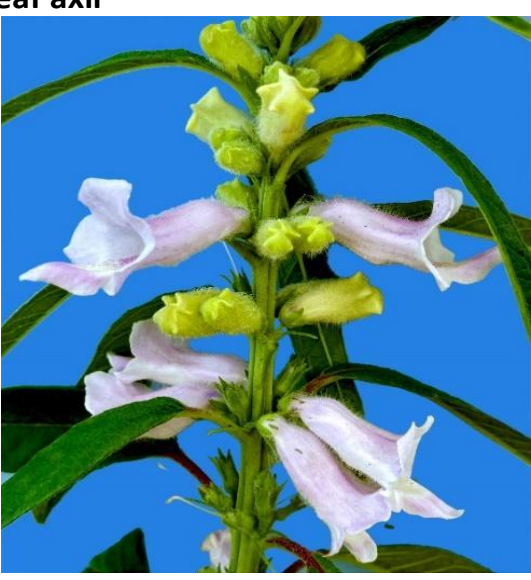

More than one flower/axil 
Fig.5 Diagram showing of different morphological traits in Sesame

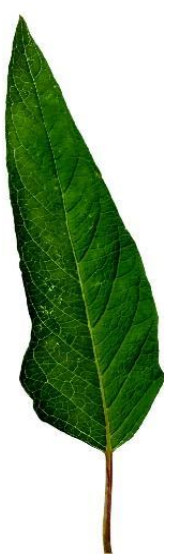

Entire

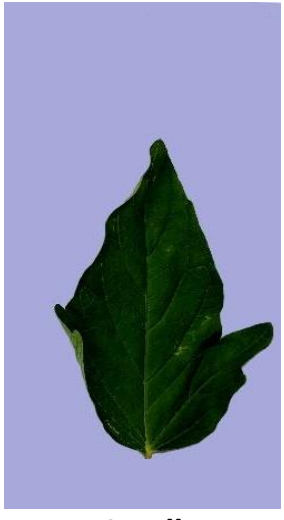

Small

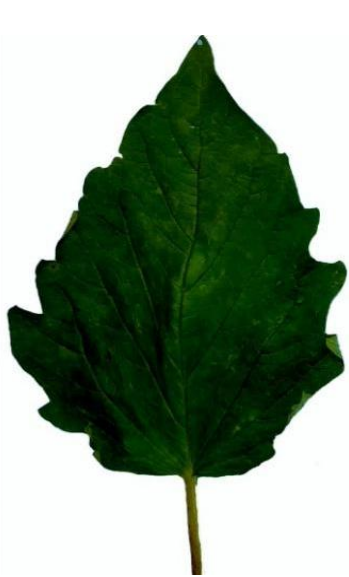

Narrowly cordate

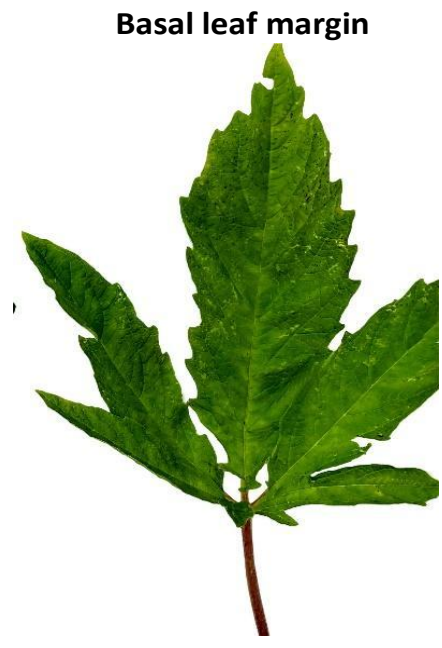

Serrate

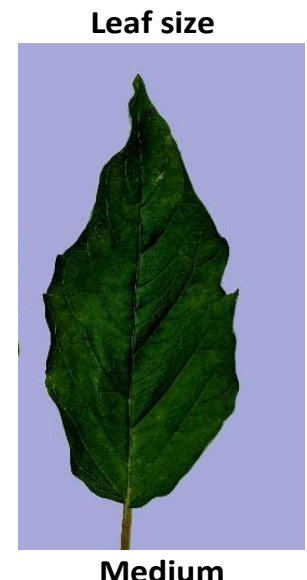

Leaf shape

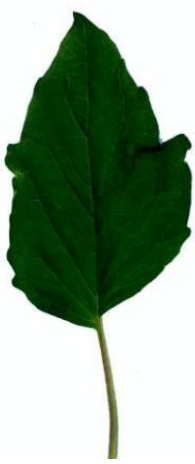

Ovate

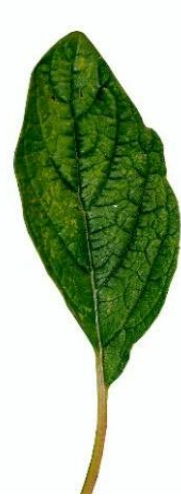

Elliptic

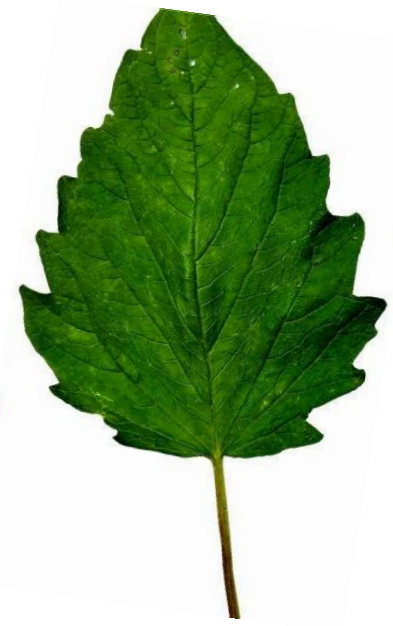

Dentate
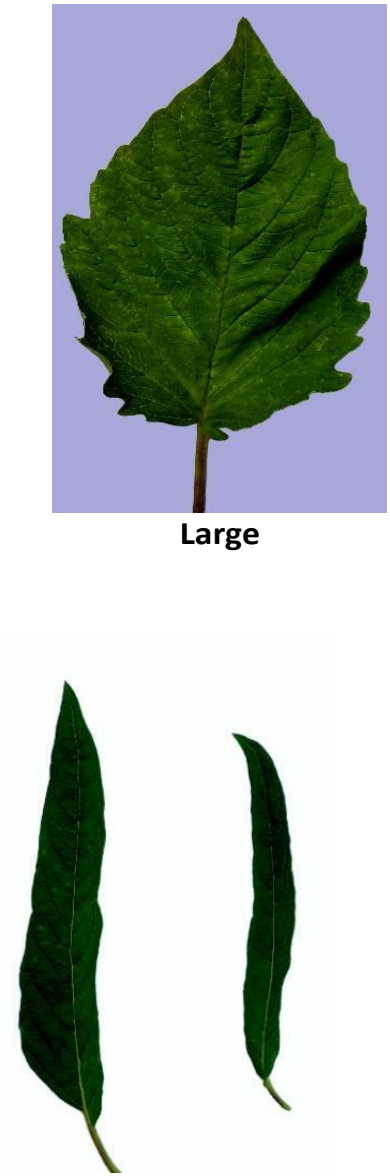

Lanceolate

Linear 
Fig.6 Diagram showing of different morphological traits in Sesame

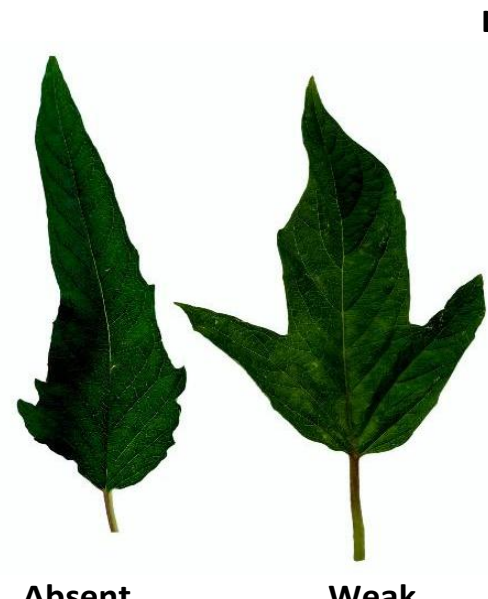

Lobe incision of basal leaf

Absent

Weak

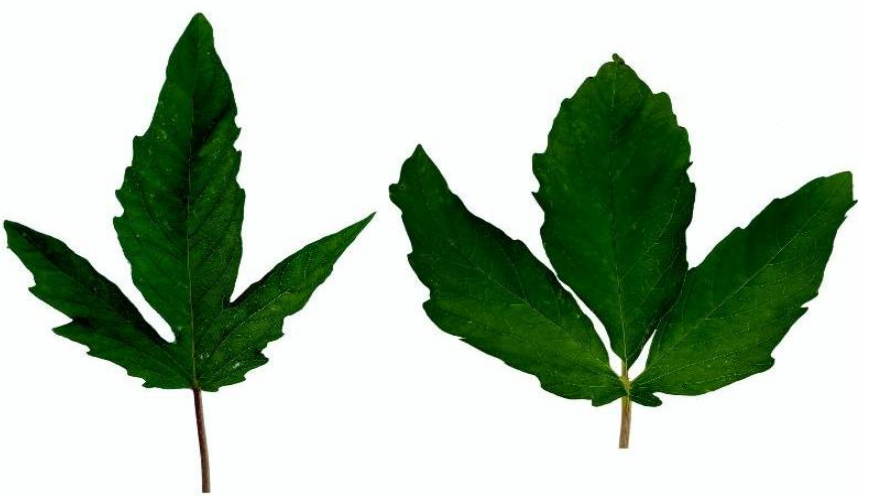

Medium

Strong

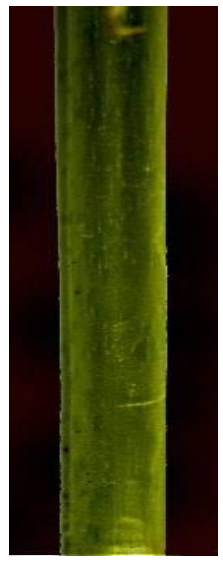

Glabrous

\section{Stem hairiness}

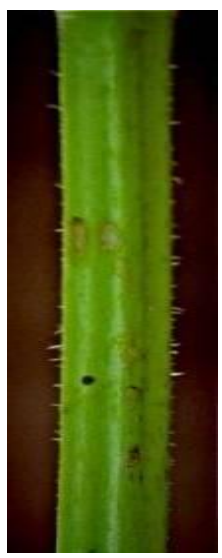

Sparse

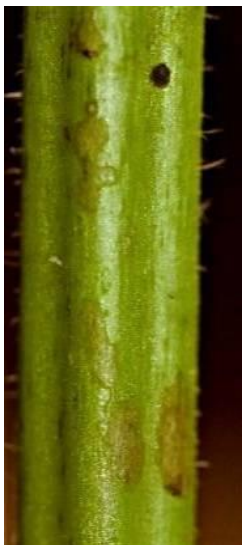

Medium
Plant growth habit

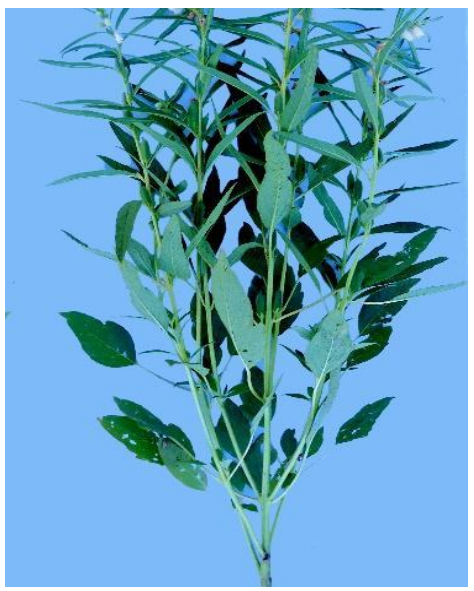

Prostrate

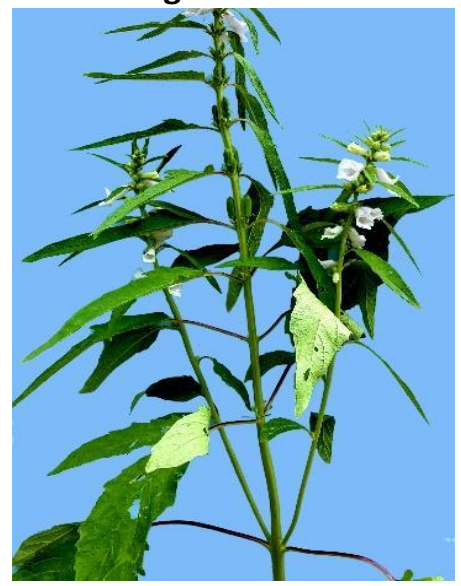

Semi-erect

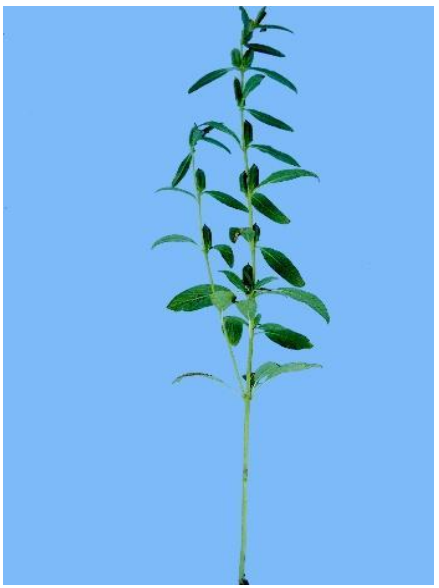

Erect 
Fig.7 Diagram showing of different morphological traits in Sesame

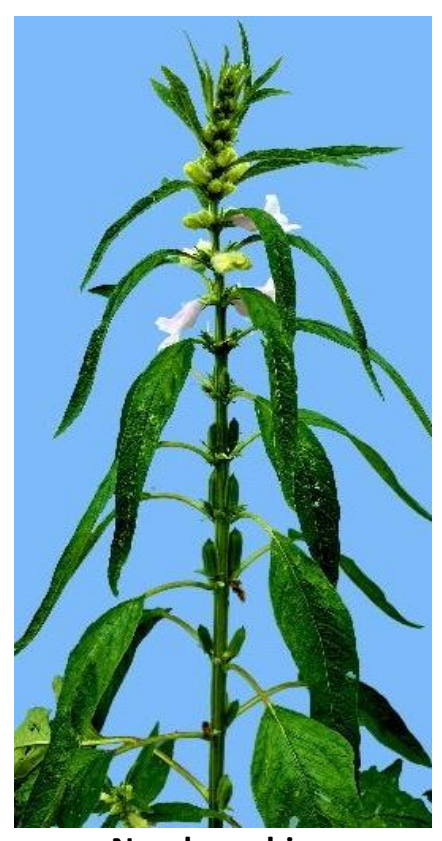

Non-branching

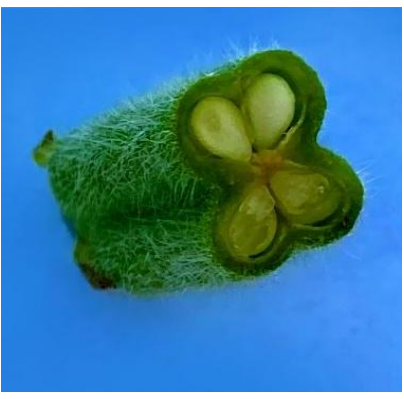

Four locules

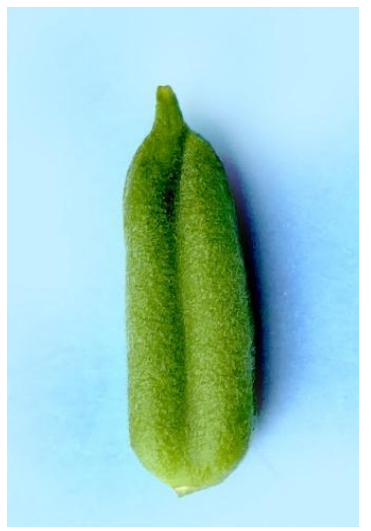

Tapered at apex

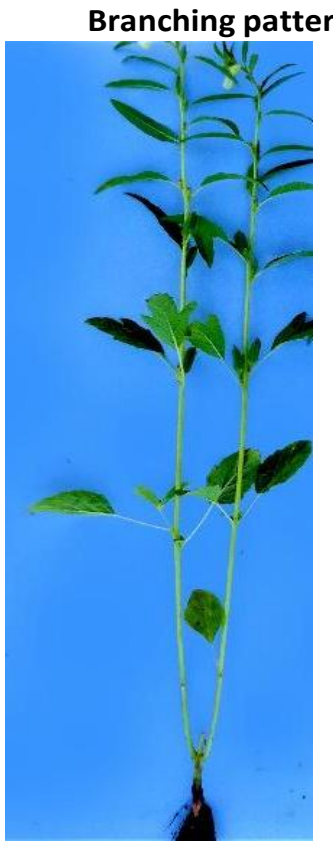

Basal branching

Number of locules/plant

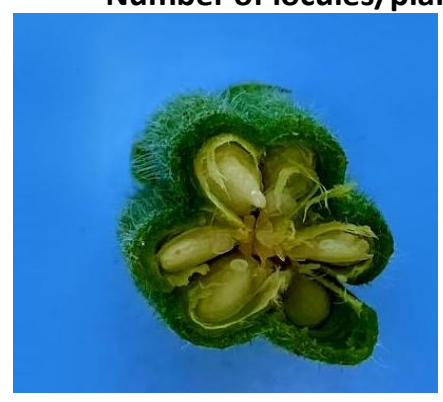

Six locules

Bicarpellate capsule shape

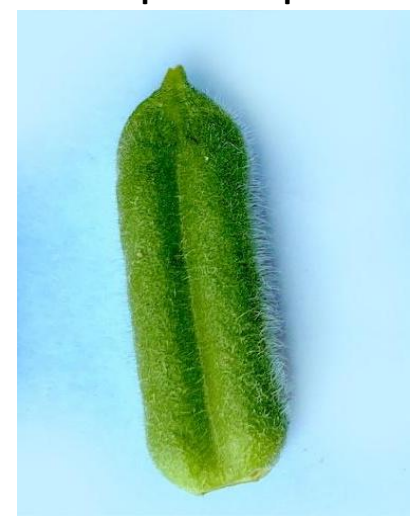

Narrow oblong

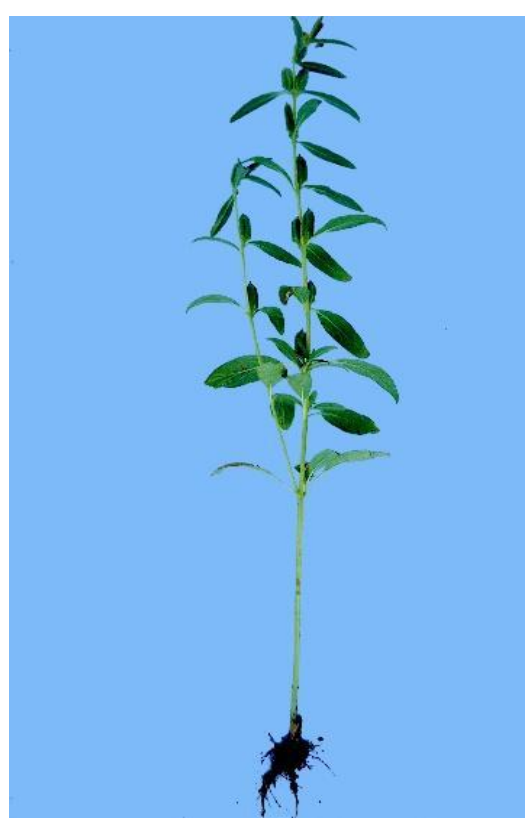

Top branching

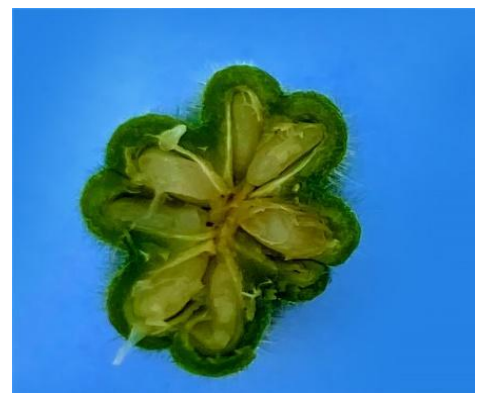

Eight locules

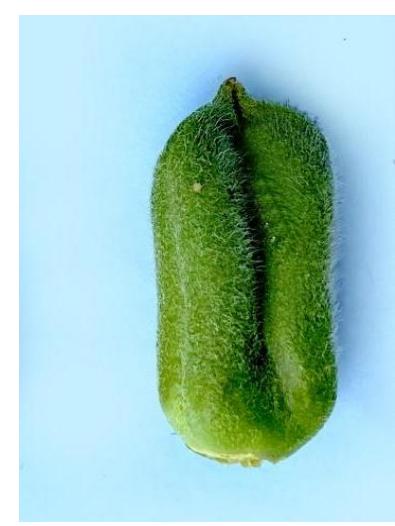

Broad oblong 
Fig.8 Diagram showing of different morphological traits in Sesame

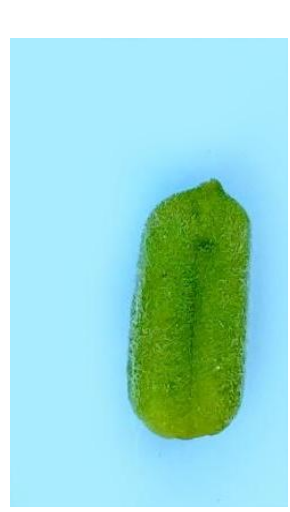

Short beak

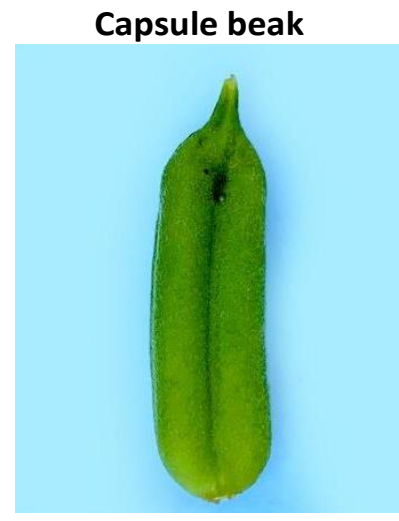

Long beak

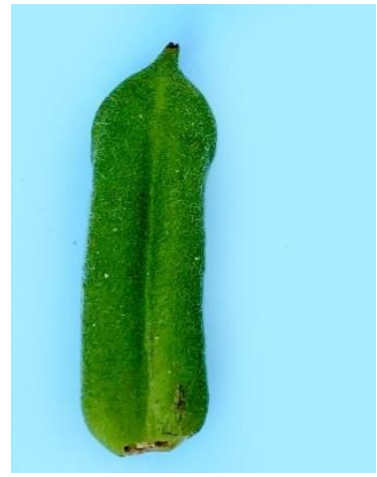

Curved beak

\section{Capsule hairiness}

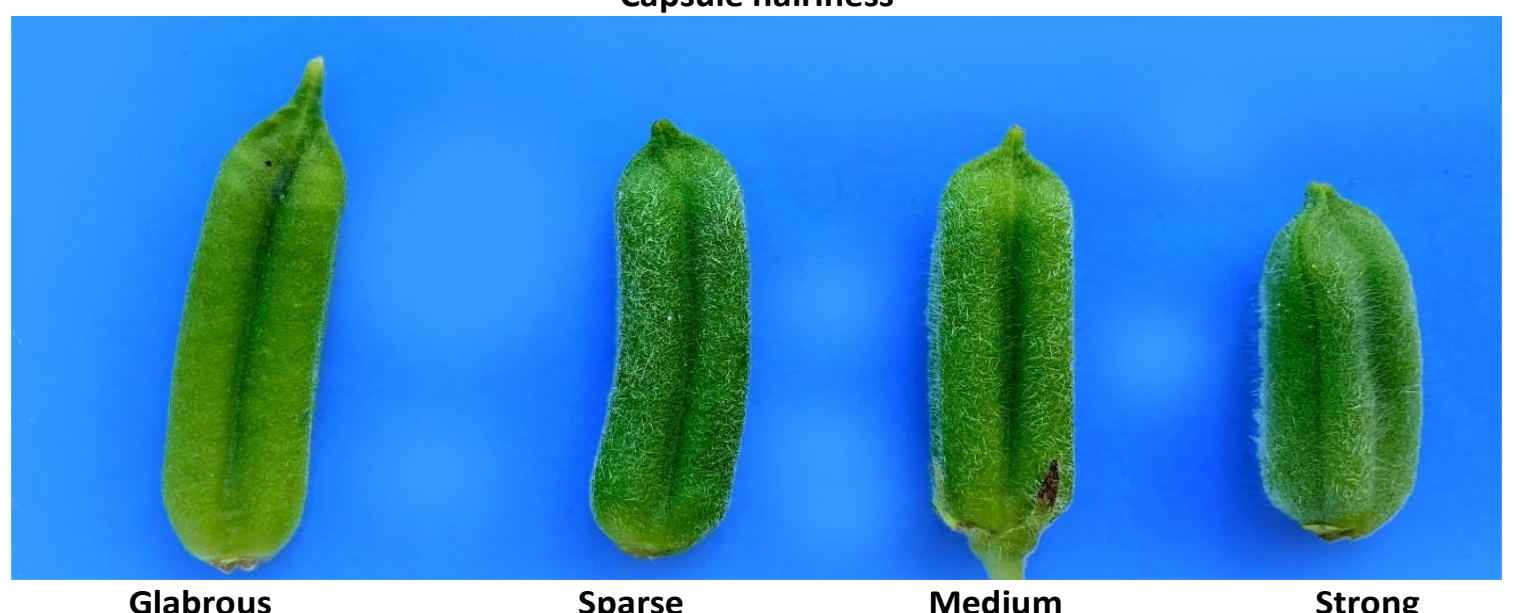

Glabrous

Sparse

Medium

Strong

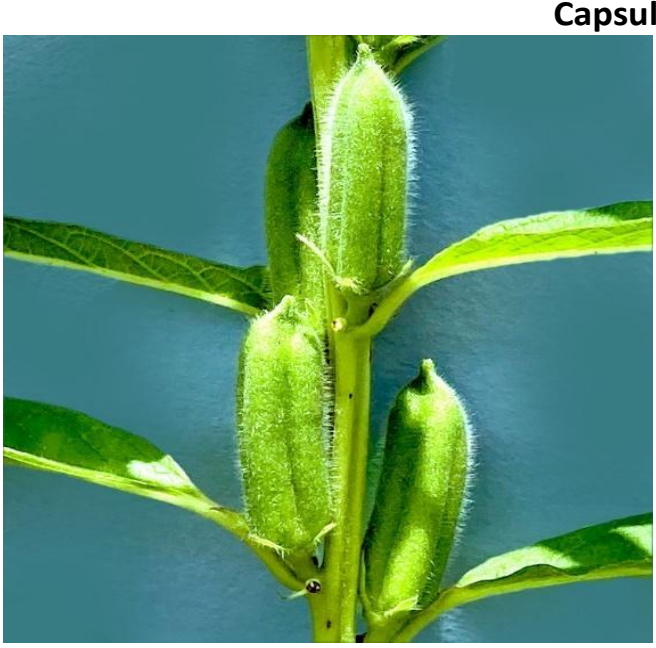

Monocapsular

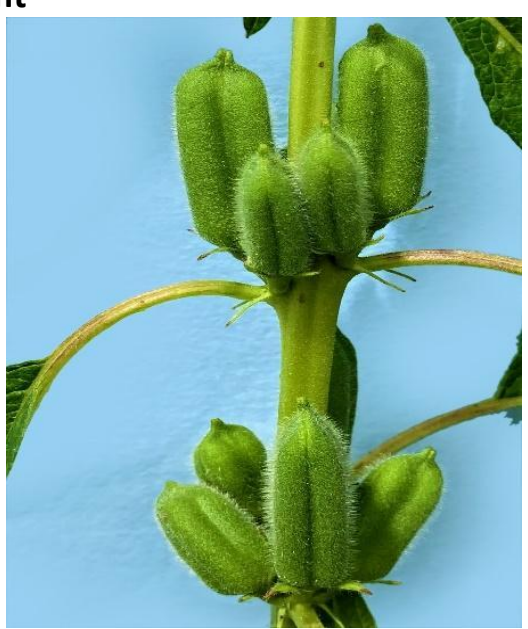

Multicapsular 
Majority of germplasm observed to be four locules per capsule (802). 15 germplasm of eight locules and 12 germplasm of six locules per capsule (Fig.7) in plant, but four locules are preferred by the breeders due to fertile seed whereas, six and eight locules per capsule are not selective due to chaffy seeds (Singh et al., 2017). Regarding shape of capsule (Fig.7) 745 germplasm exhibited narrow oblong bicarpellate capsule shape, broad oblong in 79 and tapered at apex in 5 germplasm only (Frary et al., 2015).

Seven hundred ninety six germplasm were having monocapsular arrangement of capsules and remaining thirty three germplasm were having multicapsular capsule arrangement (Fig.8). Langham, 2007 stated that the arrangement of capsules character is governed by a single gene, and the recessive allele produces triple capsules. As with branching, light also has an effect on the formation of the capsules.

Regarding corolla colour (Fig.4), 752 germplasm exhibited white with pink shading, followed by white with deep pink shading in 46 and white colour in 31 germplasm. Yellow/straw colour and Brown/tan colour of dry capsule observed in 814 germplasm and 15 germplasm respectively. Colour of capsules is depended on moisture in air, soil and maturity of capsule. It is good to harvest sesame when 80 per cent of the capsules show yellowing and leaves are dropping off (Langham et al., 2007). Five hundred six germplasm exhibited short type of capsule beak whereas, 229 germplasm long type beak and 94 germplasm curved capsule beak (Fig.8). Singh et al., (2017) and Suhasini (2006) suggested that short capsule beak helps to less shattering which reflects in yield increase and farmers preference.

In conclusion it has been observed in 829 germplasm that majority of sesame germplasm possess semi-erect plant growth habit with basal branching pattern. Abundance of germplasm exhibited medium leaf size with ovate middle leaves shape and linear top leaves shape. Entire basal leaf margin, lobe incision of basal leaf found absentia in most of germplasm. Regarding colour traits, most of germplasm exhibited white with pink shading of corolla colour in our study. In respect to hairiness, exhibited sparse stem hairiness, sparse leaf hairiness, dense corolla hairiness and strong capsule hairiness in most of germplasm. Majority of germplasm observed to be four locules per capsule in plant with narrow oblong bicarpellate capsule shape and one flower/leaf axil. Whereas, maximum of germplasm having short capsule beak, monocapsular capsules arrangement with yellow/straw colour of dry capsule. Further, the identified variability can be selected for developing varieties with unique identification, diverse traits and broaden genetic base. Above study revealed some of distinct characteristics of varieties and indicated that diversity exist in collected varieties due to variation in genetic makeup but more study required on other traits also which are not studied at genetic level. The unique lines possessed exclusive variability and unique features which need safe conservation and sustainable utilization in future sesame varieties development for issues like intellectual property rights. This study will be useful for breeders, researchers and farmers to identify the varieties and conservation of beneficial genes for crop improvement.

\section{References}

Abate, M. and Mekbib, F. 2015. Study on genetic divergence in low-altitude sesame (Sesamum indicum L.) germplasm of Ethiopia based on agro morphological traits. J. Adv. Stud. Agric. Biol. 2(3): 78-90. 
Amme, S., Rutten, T., Melzer, M., Sonsmann, G., Vissers, J. P. C., Schlesier, B., and Mock, H. P. 2005. A proteome approach defines protective functions of tobacco leaf trichomes. Proteomics. 5:2508-2518.

Ashri, A. 1998. Sesame breeding. Plant Breed. Rev. 16:179-228.

Baum, M., Grando, S., Backes, G., Jahoor, A., Sabbagh, A. and Ceccarelli, S. 2003. QTLs for agronomic traits in the Mediterranean environment identified in recombinant inbred lines of the cross 'Arta' $\times$ H. spontaneum 41-1. Theor. Appl. Genet. 107:1215-1225.

Bedigian, D. 2004. Slimy leaves and oily seeds: Distribution and use of wild relatives of sesame in Africa. Econ. Bot. 58:S3-S33.

Bhoot, H. V., Sharma, L. K., Kulkarni, G. U., Ravat, U. and Rathva, S. 2019. Characterization of sesame genotypes through morphological characters. Int. J. Pharmacogn. Phytochem. Res. 8(3): 3132-3138.

Deepthi, P., Shukla, C. S., Verma, K. P. and Siva Sankar Reddy, E. 2014. Yield assessment and influence of temperature and relative humidity on charcoal rot development in sesame (Sesamum indicum L.). The Bioscan. 9:193-195. Dep.Agric. India. Bot. 18: 127-147.

Federer, W. T., 1956. Augmented (or hoonuiaku) designs. Hawaii. Plant Research, 2: 191-208.

Frary, A., Tekin, P., Celik, I., Furat, S., Uzun, B. and Doganlar, S. 2015. Morphological and Molecular Diversity in Turkish Sesame Germplasm and Core Set Selection. Crop Sci. 55:702-711.

Gour, L., Dubey, R. K., Singh, S. K. and Tiwari, S. 2018. MorphoDiversification Study ofIndigenous Gene-Pool of Pisum sativum L. at Madhya Pradesh, India. Int. J. Curr.
Microbiol. App. Sci. 7(03): 2533-2542.

IPGRI and NBPGR. 2004. Descriptors for Sesame (Sesamum spp.). International Plant Genetic Resources Institute, Rome and National Bureau of Plant Genetic Resources, New Delhi, India.

Jadhav, M. G., Chaudhari, G. B., Patil, T. R., and Patil, S. C. 2015. JLT-408 A New High Yielding Sesame Variety for Maharashtra State. Electron. J. Pl. Breed. 6(1): 118-124.

Langham, D. R. 2007. Phenology of Sesame. Issues in new crops and new uses. J. Janick and A. Whipkey (eds.). ASHS Press, Alexandria, VA.

Ozcinar, A. B. and Sogut, T. 2017. Analysis of Sesame (Sesamum indicum L.) Accessions Collected From Different Parts of Turkey Based on Qualitative and Quantitative Traits. Ekin J. 3(1):45-51.

Palakshappa, M. G., Harshiya Banu, Parmeshwarappa, S. G., Rajani Bisen, Nagappa, H. and Pooja Holeyannavar. 2020. DUS Testing of Sesame (Sesamum indicum L.) Accessions Using Morphological Descriptors and Evaluation for Foliar Diseases of Sesame. Int. J. Curr. Microbiol. App. Sci. 9(01): 1837-1852.

Prasad, R. 2002. Text Book of field Crops Production. Indian Council of Agricultural Research, New Delhi, p 821.

Singh, B., Bisen, R. and Tiwari, A. 2017. DUS Testing of Sesame (Sesamum indicum L.) varieties using Morphological Descriptors. Bull. Env. Pharmacol. Life Sci. 6(1) 2017 512.

Suhasini, K. S. 2006. Characterization of sesame genotypes through morphological, chemical and RAPD markers. M.Sc. thesis submitted to the University of Agricultural Sciences. Dharwad. 
Tian, D., Tooker, J., Peiffer, M., Chung, S. H. and Felton, G. W. 2012. Role of trichomes indefense against herbivores: Comparison of herbivore response to woolly and hairless trichome mutants of tomato (Solanum lycopersicum). Planta. 236:1053-1066.

Upadhyaya, H. D., Yadav, D., Dronavalli, N.,
Gowda, C. L. L. and Singh, S. 2010. Mini core germplasm collections for infusing genetic diversity in plant breeding programs. Electron. J. Pl. Breed. 1 (4): 1294-1309.

Weiss, E. A. 1983. Oilseed Crops, Longman, New York, 660.

\section{How to cite this article:}

Nitesh Kumar Panwar and Rajani Bisen. 2020. Evaluation Studies to Indicate Wide Diversity in Qualitative Traits of Sesame Germplasm in Madhya Pradesh Region. Int.J.Curr.Microbiol.App.Sci. 9(09): 2424-2438. doi: https://doi.org/10.20546/ijcmas.2020.909.302 